\title{
Examining the relationship between joint range of motion and serve speed and hit
}

\author{
Soyal M. ${ }^{1 \mathrm{BCDE}}$, Kaya M. ${ }^{2 \mathrm{ABCDE}}$, Çelik N.M. ${ }^{3 \mathrm{DE}}$ \\ ${ }^{1}$ Physical and Sport College, Istanbul Gelişim University, Istanbul, Turkey \\ ${ }^{2}$ Faculty of Sport Sciences, Erciyes University, Kayseri, Turkey \\ ${ }^{3}$ Physical and Sport College, Batman University, Batman, Turkey
}

Authors' Contribution: A - Study design; B - Data collection; C - Statistical analysis; D - Manuscript Preparation; E - Funds Collection.

\begin{abstract}
Purpose: $\quad$ In this study, the relationship between the joint range of motion, and the serve speed and hit rate of tennis players was examined. The voluntary participants of this study are tennis players in the university tennis team.

Material: $\quad$ Twelve male students aged 18-25 voluntarily participated in the study. Participants were individuals, who professionally played tennis with a license. Certain parameters of the participants such as the upper extremity joint range of motion, extension and flexion angles of the elbow joint, abduction angle of the shoulder joint, and flexion and extension angles of the wrist were measured through standard plastic 12 goniometers. Similarly, the hit values were examined via the Revised Dyer Wall Test and serve speed values were examined by using the Stalker solo 2 brand radar. Pearson correlation analysis was used to examine the relationship between the joint range of motion and the serve speed and hit rate of the participants. The values below $p$ $<0.05$ were considered as significant.
\end{abstract}

Results: In the study, it was determined that there was a moderate positive correlation between wall test and shoulder abduction ( $p<0.05, r=.599)$; similarly, there was a high positive correlation between wall test and wrist extension ( $p<0.05, r=671)$; there was a high positive correlation between wall test and wrist flexion ( $p<0.05, r=638$ ); there was a high positive correlation between abduction of the shoulder and wrist extension ( $p<0.05, r=, 603)$; there was a very high positive correlation between wrist extension and wrist flexion ( $p<0.001, r=819)$, and it was determined that there was no significant relationship between the other parameters $(p>0.05)$

Conclusions: In conclusion, in this study, it was determined that the joint range of motion has a positive relationship with both serve speed and hits.

Keywords: tennis, joint range of motion, agility, serve speed.

\section{Introduction}

Tennis serve requires optimal force, flexibility, timing and coordination of various parts of the human body. Therefore, serve performance depends on the complexity of many interdependent factors. Among these, one of the most important is undoubtedly the muscle strength and joint range of motion [1]. The mobility of the human body is provided by the muscles, the skeletal system, the ligaments and the tendons. Mobility is the ability to make the movement in different directions with a joint range of motion [2]. Range of motion is the intended movement that can be achieved at the required speed and in a wide angle. In another definition, it is the range of motion of joints and soft tissues as a response to active and passive tensions. Motions occur under the conditions defined by the joints, muscles, ligaments and tendons and under the neurophysiology directing conditions. Flexibility is very important in sport. It is one of the key basic requirements for an athlete to perform his/her skills easily with large angles. Faster and more ergonomic movements depend on the range of motion, in other words, the flexibility. Factors affecting the range of motion can be listed as; Joint structure (anatomical and biomechanical properties), gender and age difference, psychological status, environmental conditions and circadian rhythm

\footnotetext{
(c) Soyal M., Kaya M., Çelik N.M., 2019

doi:10.15561/20755279.2019.0305
}

(time of the day, heat status), training level, fatigue, and warming up [3]. The mobility of the human body is provided by the muscles, the skeletal system, the ligaments and the tendons. Mobility is the ability to make the movement in different directions with a joint range of motion [2]. ROM (Range of Motion) values are important for arranging the exercise programs for the training of active athletes and in the follow-up of the performance of the athletes [4]. In general, the goniometer has been used for measuring the joint ranges [5]. Since the serve speed of professional tennis players has reached $250 \mathrm{~km} / \mathrm{h}$, in modern tennis, serve has become very significant because of its mechanical advantage [6]. Strength and joint range of motion are among the most important parameters of serve and they should be improved through trainings. It has been reported by various authors that the strength and joint range of motion training increase functional goals and athletic performance in tennis [7].

The aim of this study is to determine the effect of the joint range of motion and some physical characteristics on the serve speed of tennis players.

\section{Materials and Method}

Participants.

Twelve male students between 18-25 years old voluntarily participated in the study. Participants were individuals, who performed tennis professionally with a 
license. Volunteers were informed before they participated in the study and their consent was taken.

Research Design.

\section{Measurement of height and weight}

Tape measure with a sensitivity of $0.01 \mathrm{~cm}$ was used for the height measurements of the volunteers. The measurements were conducted while the volunteers were barefoot. Measurements were carried out while the participants were head upright, with bare feet on the ground, the knees stretched, the heels adjacent and the body upright. The body weights were measured with bare feet and the minimal clothing through a weighing scale with $0.1 \mathrm{~kg}$ precision.

\section{Measurements of Joint range of motion}

In line with the purposes of the tests, 20-minute warmup exercises were conducted by the participant subjects before the measurements. All measurements were performed at the determined positions and at the maximal points where the subjects reached and kept this position for two seconds. During the measurement, the subjects were bare feet and wearing shorts. The pivot points used in the goniometric measurements of joint range of motion were taken as reference in this study [1, 8]. Certain parameters of the participants such as the upper extremity joint range of motion, extension and flexion angles of the elbow joint, abduction angle of the shoulder joint, and flexion and extension angles of the wrist were measured through standard plastic 12 goniometers. Elbow flexion and extension was performed and evaluated while the elbow bent while the volunteer was at sitting or standing and neutral position, wrist and interphalangeal joints extended and the elbow range of motion aligned. The distal arm of the Goniometer was aligned parallel to the axis of the forearm. The proximal arm of the Goniometer was aligned parallel to the humerus. Then the volunteer was asked to actively stretch and extend. $0{ }^{\circ}$ was accepted as the starting point. In measuring the shoulder abduction, the volunteer was in the upright position. The shoulder and elbow were fully extended with the wrist and the forearm and hand were pronated slightly while the arm was slightly rotated inside. The volunteer was asked to raise his upper extremity and the measurement was performed on an axial plane [9].

\section{Vertical jump test}

Vertical jump performances of athletes were measured by electronic smart speed lite system. Vertical jump test was applied after 15 minutes of active warming; 5-minute running, 5-minute short sprints, and 5-minute stretching moves. When the athletes felt ready, they jumped to the highest point they could. Then they landed on the mat. Jumping distances of the athletes were measured electronically in $\mathrm{cm}$ and the best of 3 attempts were recorded [10].

\section{Medicine ball throwing test}

For the medicine ball throwing test, the athlete was asked to stand at the designated starting point. On his knees, the athlete was asked to throw the medicine ball forward over his head in a throw-in position. The first point of contact of the medicine ball with the ground was determined. The distance between the starting point and the first spot where the ball hit the ground were measured and recorded. The best of the two trials were taken into consideration $[11,12]$.

Revised dyer wall test (RDD)

This test was developed to determine tennis skills against a board or wall. In this test, as many hits as possible on the board or wall are recorded within the designated time. Application of the test: a 7-cm thick net line is drawn on the wall or board ( $3 \mathrm{~m}$ height $-4.5 \mathrm{~m}$ wide). The line must be $91.7 \mathrm{~cm}$ above the floor. A border line is drawn on the floor 20 feet $(6 \mathrm{~m})$ away from the panel or wall. The subject who starts the test will stand behind the border line and hits the ball over the net for 30 seconds. After a trial, 3 consecutive tests are performed. Each hit to the wall is a score and the total score of 3 tests is evaluated $[13,14]$.

Serve speed

Ball Speed Measurement in Serve; for the measurement of the ball speed, all the serves are shot in a closed tennis court in order to control the effect of the air. Subjects were asked to warm up until they reached the highest serve speed. 3 minutes after the warm up, the test phase was started and they were asked to perform 5 serves at the highest speed possible. Radar (Stalker solo 2 ) was used for the measurement of the ball speed. The radar used in the measurement of the ball speed was fixed to the middle (net) line. In accordance with the rules of tennis, backhand serve was required sending the ball to the return point, and the serve was not recorded as valid if the ball was dropped out of the net or outside the service box (out). The feedbacks of the speeds were reported to the players for the highest effort. All serves were placed in the left service box (right side) for right-handed players, and in the right service box (left side) for lefthanded players. All tennis players were instructed to use the straight serve technique and were evaluated by three tennis trainers. For the data analysis, the fastest $(\mathrm{km} / \mathrm{h})$ of the 5 serves players scored was analyzed as the maximal service (Vmax) $[15,16]$.

Statistical Analysis.

In this study, SPSS 24 package program was used to obtain statistical results and the mean and standard deviation of the measured and tested variables of all subjects were calculated. Statistically, values below $\mathrm{p}$ $<0.05$ were accepted as significant. Pearson correlation analysis was used to examine the relationship among the data.

\section{Results}

Examining the Table 1, we determined that the age average of participants was $22.00 \pm 2.13$ years, their average height was $180.16 \pm 2.85 \mathrm{~cm}$, and their body weight average was $73.33 \pm 2.93 \mathrm{~kg}$.

Examining the Table 2, it was determined that the vertical jump average was $45.08 \pm 4.46$, Medicine Ball throw average was $6.05 \pm .34$, serve speed average was $117.57 \pm 8.01$, and the wall test average was $63.75 \pm 4.30$.

Examining the Table 3, it was determined that the 
Table 1. Demographical Characteristics of Participants

\begin{tabular}{lllll}
\hline Variables & $\mathbf{n}$ & $\mathbf{X} \pm$ SD & minimum & maximum \\
\hline Age (year) & 12 & $22.00 \pm 2.13$ & 18.00 & 25.00 \\
Height $(\mathbf{c m})$ & 12 & $180.16 \pm 2.85$ & 175.00 & 185.00 \\
Body Weight $(\mathrm{kg})$ & 12 & $73.33 \pm 2.93$ & 69.00 & 78.00 \\
\hline
\end{tabular}

Table 2. Average results of selected motor characteristics of participants

\begin{tabular}{lllll}
\hline Variables & $\mathbf{n}$ & $\mathbf{X} \pm$ SD & minimum & maximum \\
\hline Vertical jump & 12 & $45.08 \pm 4.46$ & 38.00 & 52.00 \\
Throwing medicine ball & 12 & $6.05 \pm 34$ & 5.47 & 6.60 \\
Serve speed & 12 & $117.57 \pm 8.01$ & 106.40 & 136.80 \\
Wall test & 12 & $63.75 \pm 4.30$ & 52.00 & 68.00 \\
\hline
\end{tabular}

Table 3. Average results of participant's joint range of motion

\begin{tabular}{lllll}
\hline Variables & $\mathbf{n}$ & $\mathbf{X} \mathbf{S D}$ & minimum & maximum \\
\hline Shoulder abd & 12 & $156.41 \pm 6.73$ & 148.00 & 173.00 \\
Shoulder add & 12 & $31.66 \pm 1.77$ & 29.00 & 35.00 \\
Elbow flexion & 12 & $145.16 \pm 2.95$ & 136.00 & 152.00 \\
Wrist extension & 12 & $69.00 \pm 4.30$ & 63.00 & 74.00 \\
Wrist flexion & 12 & $74.83 \pm 3.15$ & 70.00 & 79.00 \\
\hline
\end{tabular}

Table 4. Analysis of correlation between the Tennis Serve Speed and other variables

\begin{tabular}{|c|c|c|c|c|c|c|c|c|}
\hline Variables & & 1 & 2 & 3 & 4 & 5 & 6 & 7 \\
\hline \multirow[b]{2}{*}{ Serve speed } & $r$ & 1 & & & & & & \\
\hline & $\mathbf{p}$ & - & & & & & & \\
\hline \multirow{2}{*}{ Wall test } & r & -.263 & 1 & & & & & \\
\hline & $\mathrm{p}$ & .408 & - & & & & & \\
\hline \multirow{2}{*}{ Shoulder abd } & $r$ & -.176 & $.599^{*}$ & 1 & & & & \\
\hline & $p$ & .584 & .040 & - & & & & \\
\hline \multirow{2}{*}{ Shoulder add } & r & .169 & -.154 & -.322 & 1 & & & \\
\hline & $p$ & .600 & .632 & .308 & - & & & \\
\hline \multirow[b]{2}{*}{ Elbow flexion } & $r$ & -.223 & .127 & .131 & -.558 & 1 & & \\
\hline & $p$ & .486 & .695 & .686 & .059 & - & & \\
\hline \multirow{2}{*}{ Wrist extension } & $r$ & -.175 & $.671^{*}$ & $.603^{*}$ & -.069 & .406 & 1 & \\
\hline & $p$ & .586 & .017 & .038 & .830 & .190 & - & \\
\hline \multirow{2}{*}{ Wrist flexion } & $r$ & -.114 & $.638^{*}$ & .478 & .314 & .206 & $.819^{*}$ & 1 \\
\hline & $\mathbf{p}$ & .724 & .026 & .116 & .321 & .521 & .001 & - \\
\hline
\end{tabular}

${ }^{*} p<0.05 * * p<0.001$

shoulder abduction average was $156.41 \pm 6.73$, shoulder adduction average was $31.66 \pm 1.77$, elbow flexion average was $145.16 \pm 2.95$, wrist extension average was $69.00 \pm 4.30$, and wrist flexion average was $74.83 \pm 3.15$.

When Table 4 was examined; it was determined that there was a moderate positive correlation between wall test and abduction of the shoulder $(\mathrm{p}<0.05, \mathrm{r}=.599)$; similarly, here was a high positive correlation between wall test and wrist extension $(\mathrm{p}<0.05, \mathrm{r}=671)$; there was a high positive correlation between wall test and wrist flexion $(\mathrm{p}<0.05, \mathrm{r}=638)$; there was a high positive correlation between abduction of the shoulder and wrist extension ( $p$
$<0.05, r=.603)$; there was a very high positive correlation between wrist extension and wrist flexion $(\mathrm{p}<0.001, \mathrm{r}=$ $819)$; there was no significant relationship between the other parameters $(\mathrm{p}>0.05)$.

\section{Discussion}

Flexibility, which is defined as the amount of motion of the joints within the normal range, is known to affect the quality of life and sport performance of the individual [17]. The aim of this study is to determine the effect of the joint range of motion and some physical characteristics on the serve speed of tennis players. 
In the study, average height values of subjects was found as $180.16 \pm 2.85$ and average body weight as 73.33 \pm 2.93 .

Elbow joint flexion angles were determined as 145.16 \pm 2.95 , shoulder joint abduction value as $156.41 \pm 6.73$ and shoulder joint adduction angle as $31.66 \pm 1.77$. The wrist flexion angle was $74.83 \pm 3.15$ and the wrist extension angle was $69.00 \pm 4.30$

In the literature, it was seen that the number of studies conducted on joint range of motion was very limited. When the similar age group values were considered for a similar study, the average of elbow joint extension values was $52^{\circ}$ and average flexion angle values were $53^{\circ}$, wrist flexion was $20^{\circ}$, and extension angle value was $16^{\circ}$. The speed of the ball in the serve was reported as $145.0 \mathrm{~km} /$ $\mathrm{h}$ [1]. These values are not similar to those of our study, and they can be explained by the fact that athletes have different joint angles.

In the study, the vertical jump values of the subjects were determined as $45.08 \pm 4.46$. Göral et al. determined that the anaerobic power values of the university tennis players were $149.41 \pm 17.47 \mathrm{~kg}-\mathrm{m} / \mathrm{sec}$ [17]. In another study, Gelen et al., determined the average of anaerobic power values of the first league tennis players as 135.1 $\pm 5.67 \mathrm{~kg}-\mathrm{m} / \mathrm{sec}$ and the second league tennis players as $100.4 \pm 14.5 \mathrm{~kg}-\mathrm{m} / \mathrm{sec}$ [18]. In the study, the average of medicine ball throwing values of the volunteers was determined as $6.05 \pm 34$. In another study, Kovacs et al., determined that the average of medicine ball throw values was $7.50 \mathrm{~m}$ in the pre-test, whereas this value was 7.69 $\mathrm{m}$ in the post-test [19]. Although these values are related with our study, the low number of numerical values is due to the fact that our study group did not perform adequate strength training.
As a result; accuracy and sustainability of each hit, the correct technique, the conditional factors and the kinematic parameters implemented during the hit are considered to have a significant role for success. The moderate positive relationship between wall test and shoulder abduction can be explained by the fact that the angle of the shoulder joint is large in abduction, and it has a significant quality in terms of hit quality and reaching the targeted point. In addition, it is seen that wrist extension and flexion have a high positive relationship with the hit accuracy. Extension of the wrist joint in the forehand stroke and the flexion of the wrist joint in the backhand stroke influence the success in meeting of the ball and the racket and the success of the hit. In the study, although there was a positive relationship between the range of motion of the shoulder joint and wrist, there was no correlation between the range of motion of the shoulder joint and wrist and the speed of hit. Finding no correlation in the hit speed can be explained by the inadequacy of participants' strength parameters.

\section{Conclusion}

This study was aimed to make an important contribution to the sports science by investigating the effect of force and stabilization trainings on joint range of motion, serve speed and hit by performing the foms test with 6-week individual force and stabilized training program and conducting the foms test before and after the training period.

\section{Conflict of interest}

The authors declare no conflict of interest.

\section{References}

1. Gelen E, Mengütay S, Karahan M. Teniste servis performansını belirleyen fiziksel uygunluk ve biyomekaniksel faktörlerin incelenmesi [Analysing physical fitness and biomechanical factors that determine tennis serve performance]. Uluslararast insan bilimleri dergisi, 2009; 6: 2. (In Turkish)

2. Akın H. Puberte Dönemi Sedanterler ile Futbolcuların Bazı Antropometrik ve Biomotorik Özelliklerinin Karşılaştırılması [Comparison of Some Anthropometric and Biomotoric Characteristics of Footballers with Puberte Period]. [Master Thesis]. Sakarya: Sosyal Bilimler Entitüsü; 1999. (In Turkish)

3. Selvi I. Farklı Branşlarda Bulunan Sporcularda ve Sedanterlerde Kas Kuvvetinin Esneklik Ile İlişkisi [The Relationship of Muscle Strength with Flexibility in Athletes and Sedanter in Different Branches]. [Master Thesis]. Atatürk Üniversitesi Sağllk Bilimleri Enstitüsü Spor Sağlık Bilimleri Anabilim Dali; 2009. (In Turkish)

4. Cleffken B, Breukelen GV, Mameren HV, Brink P, Damink SO. Test-retest reproducibility of elbow goniometric measurements in a rigid double-blinded protocol. Intervals for distinguishing between measurement error and clinical change. J Shoulder Elbow Surg, 2007; 16: 788- 794. https://doi.org/10.1016/j.jse.2007.02.134

5. Ake A, Moussa M, Alnahdı M. On geographical variations in the normal range of joint motion.
Clin.Orth.and Related Rese. 1987; 10: 229- 231. https://doi.org/10.1097/00003086-198809000-00040

6. Brody H. Serving Strategy. In: ITF Coaching and Science Review, 31, December, 2-3. 2003.

7. Treiber FA, Lott J, Duncan J, Slavens G, Davis H. Effects of the raband and lightweight dumbbell training on shoulder rotation torque and serve performance in college tennis players. American Journal of Sports Medicine, 1998; 26 (4), 510- 515. https://doi.org/10.1177/03635465980260040601

8. Norkin CC, White DJ. Measurement of Joint Motion: A Guide to Goniometry. Philadelphia: FA Davis Company; 1985.

9. Erdoğan F, Şenkal E, Çiftçi M, Doğan E, Keskinbora M, Şahin M, Ceran Ö. Effects of obesity on upper extremity range of motion in children. FNG \& Bilim Tip Dergisi, 2016; 2(3):195-200. (In Turkish) https://doi.org/10.5606/fng.btd.2016.035

10.Serin E. Anaerobik Dayanıklılı İle Dikey Sıçrama Arasındaki İlişki, [Relationship Between Anaerobic Endurance and Vertical Jump]. [Master Thesis]. Konya: Selçuk Üniversitesi Sağlık Bilimleri Enstitüsü, Antrenörlük Eğitimi Anabilim Dalı; 2015. (In Turkish) https://doi.org/10.17155/spd.86991

11.Gozzoli C, Simohamed J, El-Hebil AM. Educational Cards Kids'Athletics, IAAF. 2006. [cited 2019 April 02]. Available from: http:// www.iaaf.org/mm/Document/imported/37264. 
pdf

12.Diker G, Zileli R, Özkamçı H, Ön S. Genç Tenis Oyuncularının BazıFizyolojikveBiyomotorÖzelliklerininDeğerlendirilmesi [Evaluation of some physiological and biomotor features of young tennis players]. Uluslararasl Spor, Egzersiz veAntrenman Bilimi Dergisi, 2017; 3(1): 25-32. (In Turkish) https://doi.org/10.18826/useeabd.296396

13.Stoebe HE. The relationship of grip strength and tennis ability. [Master's thesis]. School of health physical education and recreation, University of Wisconsin-La Crosse; 1976.

14.Cannon JA. A test of predict ability for the beginning tennis player. [Master's thesis]. The Graduate Faculty of Texas Technological College; 1967.

15.Cohen DB, Mont MA, Campbell KR, Vogelstein BN, Loewy JW. Upper Extremity Physical Factors Affecting Tennis Serve Velocity, The American Journal of Sports Medicine, 1994; 22(6):746- 750. https://doi.org/10.1177/036354659402200604

16.Avar P, Akça F. 10-12 Yaş Grubu Tenisçilerin Türkiye Klasman Sıralamalarına Göre Antropometrik Özellikleri ve Servis Hızlarının İncelenmesi [Investıgatıon of
Anthropometric Characterıstics and Serve Speeds According to Turkey Rankıngs In 10-12 Age Group Tennis Players]. Spormetre Beden Eğitimi Ve Spor Bilimleri Dergisi, 2013; 11(1): 35-40. (In Turkish) https://doi.org/10.1501/Sporm_0000000236

17.Göral K, Saygın Ö, Karabey K, Gelen E. Tenisçiler İle Voleybolcuların Bazı Fiziksel Uygunluk Özelliklerinin Karşılaştırılması [Comparison of Some Physical Fitness Parameters of Volleybal Players and Tennis Players]. E-Journal of New World Sciences Academy 2009; 4(3):2b0022. (In Turkish)

18.Gelen E, Saygın Ö, Karahan M, Karacabey K. I. ve II. Ligdeki tenisçilerin fiziksel uygunluk özelliklerinin karşılaştırılması. [Comparison of physical fitness characteristics of tennis players in the I. and II. League]. Firat University Journal of Health Sciences, 2006; 20 (2): 119-127. (In Turkish)

19.Kovacs MS, Pritchett R, Wickwire PJ, Green JM, Bishop P. Physical performance changes after unsupervised training during the autumn/spring semester break in competitive tennis players, $\mathrm{Br} J$ Sports Med, 2007; 41(11): 705-710. https://doi.org/10.1136/bjsm.2007.035436

\section{Information about the authors:}

Soyal M. (Corresponding author); http://orcid.org/0000-0001-6528-0275; mehmetsoyal3838@hotmail.com; Physical and Sport College, Istanbul Gelisim University; Cihangir Mahallesi Şehit Jandarma Komando Er Hakan Öner Sk. No:1 Avcılar/ İstanbul, Turkey.

Kaya M.; http://orcid.org/0000-0002-2438-2678; mustafakayaerciyes@gmail.com; Faculty of Sport Sciences, Erciyes University; Erciyes University, 38039 Kayseri, Turkey.

Çelik N.M.; http://orcid.org/0000-0001-6403-6262; nmcelik42@hotmail.com; Physical and Sport College, Batman University; Batman University, Batı Raman 72100, Batman, Turkey.

\section{Cite this article as:}

Soyal M, Kaya M, Çelik NM. Examining the relationship between joint range of motion and serve speed and hit. Physical education of students, 2019;23(3):142-146. https://doi.org/10.15561/20755279.2019.0305

This is an Open Access article distributed under the terms of the Creative Commons Attribution License, which permits unrestricted use, distribution, and reproduction in any medium, provided the original work is properly cited http://creativecommons.org/licenses/by/4.0/deed.en

Received: 15.03 .2019

Accepted: 25.04.2019; Published: 28.06.2019 